УДК 378.147.016:640.4

DOI:

Юрій Безрученков, кандидат педагогічних наук, доцент кафедри туризму, готельної і ресторанної справи, Луганського наџіонального університету імені Тараса Шевченка

\title{
ЕЛЕКТРОННА ОСВІТА: РЕАЛІЗАЦІЯ В УКРАЇНІ
}

Тенденції розвитку вищої освіти України значною мірою змінилися в сучасних умовах у зв'язку з пандемією коронавірусної інфекції та введенними з иієї причини обмеженнями у роботі ЗВО. У статті розглянуті основні проблеми реалізації електронної освіти та ї̈ переваги в освітньому процесі у порівнянні з традиційними методами. Проведений аналіз як світового досвіду, так $і$ сьогоднішнього положення електронної освіти України. Досліджені певні перспективи подальшого впровадження дистанційної форми навчання та визначені пріоритети розвитку електронної освіти у найближчі роки.

Ключові слова: електронна освіта; е-освіта в Украӥні; реалізація цифрового навчання; застосування електронної освіти; перспективи дистанційної освіти в Україні.

Лim. 8.

Yuriy Bezruchenkov, Ph.D.(Pedagogy), Associate Professor of the Tourism, Hotel and Restaurant Business Department Luhansk Taras Shevchenko National University

\section{E-EDUCATION: IMPLEMENTATION IN UKRAINE}

Trends in the development of higher education in Ukraine have changed significantly in modern conditions in connection with the pandemic of coronavirus infection and the resulting restrictions on the work of higher education institutions. The article analyzes the current state of application of e-education in Ukraine. The legislative base of Ukraine which serves as a prerequisite for the development of e-education, its features of implementation in the educational process, outlines the main advantages, problems and further prospects for the development of distance learning in the context of globalization in the world. The article states that the main principle of eeducation is the establishment of interactive communication, which should be carried out between the student and the teacher. At the same time, there is no need to ensure their direct participation.

It is noted that distance learning, which is part of e-learning, in Ukraine can be attributed to didactic categories that do not have a clear definition on the one hand, and the lack of a full legal framework to regulate the process of e-learning is not yet fully formed. This is primarily due to the lack of a unified concept of this system due to the fact that distance education has not been widely used.

Researchers are comprehensively addressing digital education, but the scientists' views on distance learning are currently polarized. Some researchers consider it a universal form of education that can replace traditional methods, while others perceive it only as an aid to the transmission of educational information to students. But many scholars agree that e-learning is a form of learning that involves the use of computer and telecommunications technology to interact with school teachers throughout their education. In addition, scientists note that this system also allows you to conduct independent work on obtaining materials using the World Wide Web and the fact that elearning saves a lot of time for all subjects of the educational process. And thanks to e-education, students get access to non-traditional sources of information. It significantly increases the efficiency of independent work, forms creative abilities, as well as promotes the search and consolidation of professional skills. On the part of teachers, distance learning helps in the application of conceptual modeling of phenomena and processes.

Keywords: e-education; e-education in Ukraine; implementation of digital learning; application of eeducation; prospects of distance education in Ukraine.

П остановка проблеми. Традиційна освіта в останні роки зазнала значних змін, каталізатором чого стали деякі глобальні процеси, що відбулися в сучасному світі. Розвиток та поширення інформаційних технологій мали значний вплив на діяльність закладів вищої освіти як за кордоном, так і в Україні. Цей фактор можна вважати одним з основних, що сприяв поліпшенню якості освіти в XXI ст. Під його впливом природним шляхом формуються спільний освітній простір та світовий ринок освітніх послуг.

Протягом останніх кількох десятиліть європейські країни намагаються зблизитися у різних напрямах своєї діяльності. Цей процес розповсюдився, у тому числі, і на систему освіти. 3 цієї причини в 1999 р. в італійському місті Болонья відбулася перша зустріч європейських міністрів освіти. Ї̈ результатом стало підписання спільної декларації, в котрій визначалися основні 


\section{ЕЛЕКТРОННА ОСВІТА: РЕАЛІЗАЦІЯ В УКРАЇНІ}

задачі та принципи створення зони вищої освіти ЄС. Україна до Болонського процесу.

Потреба у прискоренні реформування системи освіти України зумовлена економічними, політичними та соціальними змінами останніх років. Доводиться спостерігати необхідність задоволення освітніх потреб осіб протягом усього їх життя, а не тільки у молодому віці. Державі потрібно забезпечити доступ як до освітньої, так і до професійної підготовки абсолютно всіх, хто володіє певними здібностями до цього. 3 цієї причини необхідно впровадити в освітній процес новітні системи інформаційного забезпечення освіти. Таким чином Україна зуміс зробити ще один крок у напрямі входження до міжнародної системи комп’ютерної інформації.

Актуальність дистанційного навчання полягає у тому, що при правильному підході до його реалізації можна досить ефективно розв'язати описані вище проблеми. Цьому сприяє глобалізація, яка прискорює зростання академічної мобільності, уніфіковує навчальні плани та методи викладання матеріалу, а також допомагає ширшому поширенню дистанційної освіти [3].

Мета викладання навчальних дисциплін в 3ВО - це всебічна підготовка фахівця з наданням йому знань та умінь, котрі би повністю відповідали умовам сучасного інформаційного суспільства. Для того, щоб досягти цього, потрібно перестати використовувати застарілі методи та підходи. В умовах XXI ст. та у зв'язку з обмеженнями через пандемію коронавірусної інфекції виникла потреба у більш ефективному застосуванні інформаційних технологій задля поширення знань. Цьому сприяють розробки дистанційних ресурсів, що допомагають досягти поставленої мети.

Електронна освіта існує відносно недовго. В їі основі лежить використання можливостей сучасних технічних засобів масової комунікації, які допомагають як зберігати, так i розповсюджувати інформацію. Через це наразі відсутня достатня кількість наукових теорії та досліджень у цій сфері. В літературі можна знайти доробки науковців які розглядають різні аспекти е-навчання (О. Чорна, К. Бугайчук, М. Федорчук, Б. Кормич, I. Арістова, Т. Кронівець, В. Цимбалюк та інші). У більшості робіт передовсім вивчалася технічна та організаційна сторона дистанційного навчання. Педагогічні та психологічні аспекти електронної освіти на сьогодні були розглянуті в невеликій за обсягом науково-теоретичній базі [4]. Світовий та український досвід впровадження практики дистанційної освіти у закладах вищої освіти уже відбувся. Він допоміг виявити деякі особливості означеної системи, що заснована на застосуванні сучасних освітніх технологій, а також новітніх методик навчання. Це стало можливим завдяки технічним засобами та способам передачі інформації через інформаційні та телекомунікаційні технології [5].

Мета статті - здійснити аналіз сучасного стану застосування електронної освіти в Україні, розглянути особливості, основні переваги, проблеми та можливі перспективи розвитку дистанційної форми навчання в контексті глобалізаційних процесів у світі.

Виклад основного матеріалу. Для входження України до єдиного освітнього простору Європи державі потрібно було впровадити кредитно-модульну систему організації навчального процесу. Її мета полягає у підвищенні ролі самостійності здобувачів освіти при роботі в ЗВО. Ефективним засобом розв'язання поставленого завдання $\epsilon$ використання системи дистанційної форми навчання [6]. 3 іiї допомогою можна отримати першу або ж другу вищу освіту, підвищити рівень своєї кваліфікації, поліпшити свої знання, обмінятися особистим досвідом чи взяти участь у діалозі на професійну тематику. При цьому не обов'язково на довгий час залишати свою сім'ю або ж роботу. У зв'язку з пандемією коронавірусної інфекції електронне навчання стало актуальним ще й тому, що перебування в обмеженому просторі закладів вищої освіти 3 великою кількістю інших людей є небезпечним 3 точки зору високого ризику зараження вірусом.

Електронна освіта до початку впровадження обмежень у 2020 р. широко почала застосовуватися не тільки в Україні, але і в інших країнах Східної Європи та Центральної Азї тощо. Відповідно до українського законодавства, під терміном “електронна освіта" заведено розуміти одну 3 форм отримання освіти, що здобувається винятково за допомогою використання інформаційно-комунікаційних технологій.

Процес прискорення розвитку електронної освіти в України почався 32003 року і продовжується по теперішній час. Так, за цей період були прийняті деякі важливі законодавчі акти та постанови, які регламентують різні аспекти електронної освіти в Україні:

- Закон України "Про Національну програму інформатизаціі” від 23.09.2003 р.;

- Постанова Кабінету Міністрів України від 23.09.2003 р. № 1494 “Програма розвитку системи дистанційного навчання на 2004-2006 pp.”;

- наказ міністра освіти та науки України № 802 від 04.12.2003 р. "Про затвердження Заходів щодо 


\section{ЕЛЕКТРОННА ОСВІТА: РЕАЛІЗАЦЯ В УКРАЇНІ}

реалізації Програми розвитку системи дистанційного навчання на 2004-2006 pp.”;

- наказ Міністерства освіти та науки України № 40 від 21.01.2004 р. "Про дистанційне навчання";

- розпорядження Кабінет Міністрів України від 15 травня 2013 р. № 386-р “Про схвалення Стратегії розвитку інформаційного суспільства в Україні";

- Закон України “Про Основні засади розвитку інформаційного суспільства в Україні на 2007-2015 роки";

- наказ Міністерство Освіти і Науки України № 1115 від 08 вересня 2020 р. “Про Деякі питання організації дистанційного навчання”.

Упровадження системи електронної освіти відбулося ще до початку пандемії коронавірусної інфекції, обмеження у зв'язку з якою сприяли переходу ЗВО до дистанційної форми навчання. Серед перших навчальних закладів, котрі скористалися новітніми технічними можливостями, потрібно виділити НАДУ при Президентові України, ЦІППО Академії педагогічних наук України, НПУ ім. М. Драгоманова тощо.

Основним принципом електронної освіти є встановлення інтерактивного спілкування, котре повинне здійснюватися між здобувачем освіти та викладачем. При цьому відсутня потреба в забезпеченні їхньої безпосередньої участі. Це допомагає самостійному засвоєнню здобувачем освіти матеріалу та отримання ним навичок відповідно до вибраного курсу.

Дистанційну форму навчання, що є частиною цифрової освіти, в Україні можна віднести до дидактичних категорій, які не мають чіткого визначення. Це передовсім обумовлено відсутністю єдиної концепції цієї системи у зв'язку 3 тим, що донедавна вона широко не використовувалася. Наразі ж погляди стосовно дистанційного навчання поляризуються. Частина дослідників його вважають універсальною формою отримання освіти, спроможною замінити традиційні методи, інші ж сприймають лише як допоміжний засіб передачі навчальної інформації здобувачам освіти [5].

Цифрова освіта - це першочергово дистанційні освітні технології, які можна використовувати в традиційному процесі навчання для того, щоб підвищити якість освіти, проте доцільніше їх використовувати у межах саме дистанційного навчання [1].

За допомогою сучасних комп'ютерних телекомунікацій можна забезпечити більш ефективну передачу знань та доступ до різних типів навчальної інформації у порівнянні 3 традиційними методиками і практиками. Проведені експерименти та дослідження показали, що якість та структура навчальних курсів, як і якість самого викладання, при дистанційній формі навчання $є$ кращою, ніж при безпосередньому контакті здобувачів освіти 3 викладачем в аудиторії закладу вищої освіти [2].

Для забезпечення більш активного залучення здобувачів освіти до навчального процесу варто використовувати сучасні електронні технології, до яких належать інтерактивні дошки, мультимедійні гіпертексти, електронні дошки оголошень тощо. Всі вони є доступними завдяки глобальній мережі Інтернет. 3 допомогою цих ресурсів виникла можливість зробити отримання знань цікавішим в порівнянні з традиційними навчальними середовищами. У процес можна інтегрувати звук, рухомі зображення і текст. Всі ці елементи створюють нове, багатше навчальне середовище, котре має нові можливості та функції. Воно допомагає в рази збільшити ступінь залучення здобувача освіти до освітнього процесу. Крім того, інтерактивні можливості, котрі виникають завдяки використанню дистанційної форми навчання 3 відповідним технічним забезпеченням, дають змогу поліпшити зворотний зв'язок, забезпечуючи постійний діалог та підтримку, яких не вистачає у традиційних системах отримання вищої освіти.

Якщо проаналізувати основні особливості дистанційної форми навчання, варто визнати, що вона не $\epsilon$ новинкою. Деякі її елементи протягом десятиліть використовуються у заочній або ж в екстрнатній формі навчання здобувачів освіти в ЗВО. При цьому електронна освіта має деякі відмінності. Саме тому не потрібно прирівнювати заочне навчання до дистанційного. Перше може бути лише прообразом другого. Саме тому наразі можна спостерігати простоту реалізації електронної освіти саме в тих університетах, що мають досвід заочного навчання. При цьому варто відзначити те, що стандарти даних форм навчання принципово відрізняються одна від одної.

Якщо говорити про заочне навчання, то воно здійснюється за чітко визначеним навчальним планом, який передбачає отримання здобувачем освіти відповідної спеціальності. При цьому така форма здобуття освіти потребує проведення, в тому числі, і очних занять для прослуховування оглядових лекцій. Також під час них можуть проводитися лабораторні роботи, складатися заліки або ж екзамени. Що стосується дистанційного навчання, воно $є$ більш демократичним, оскільки не передбачає проведення сесій в описаному форматі. При заочній формі пересилка друкарських матеріалів 


\section{ЕЛЕКТРОННА ОСВІТА: РЕАЛІЗАЦІЯ В УКРАЇНІ}

здійснюється за допомогою пошти. У дистанційному ж навчанні цей процес відбувається через комп'ютерні або ж телекомунікаційні технології.

Таким чином, під дистанційним навчанням мається на увазі форма навчання, що передбачає використання комп'ютерних та телекомунікаційних технологій, за допомогою яких можна здійснити інтерактивну взаємодію викладачів 3 ВО зі здобувачами освіти протягом всіх етапів отримання освіти. Крім того, означена система дає змогу проводити і самостійну роботу 3 отримання матеріалів за допомогою Всесвітньої мережі Інтернет. Електронне навчання значно економить час усіх суб' єктів освітнього процесу. Серед його переваг варто виділити такі:

- цілодобовий доступ до навчальних матеріалів;

- постійна підтримка;

- можливість отримання консультацій викладачів та методистів;

- відеолекції у режимі реального часу;

- використання віртуальних тренажерів;

- застосування новітніх технологічних рішень для забезпечення ефективного процесу отримання знань.

Дистанційна форма навчання відрізняється деякими перевагами в порівнянні зі стандартними методами отримання знань. Передовсім варто відзначити значну інформативність електронної освіти, їі доступність для більшої кількості громадян та економічну ефективність застосування. Крім того, дистанційна форма навчання може здійснюватися при мінімальних затратах енергії на засвоєння матеріалу, при цьому будучи мобільною й комфортною у порівнянні 3 традиційними методами. 3 цих причин групові заняття в аудиторіях поступово відходять у минуле, змінюючись лекціями через відеозв'язок. Цьому сприяли, в тому числі, і обмеження у зв'язку з пандемією коронавірусної інфекції. Подібна ситуація спостерігається не тільки в Україні, але й у багатьох інших країнах світу.

Серед переваг електронної освіти також варто виділити й деякі інші важливі фактори, такі як більша можливість індивідуалізації навчання, вибір оптимального темпу та швидкості засвоєння знань, вища якість контролю через використання модульної системи та досить ефективне тестування здобувачів освіти. Попри те, що дистанційна освіта не $є$ варіантом заочного навчання, в ідеальних умовах без обмежень у вигляді неможливості відвідування 3ВО, найбільш доцільно їі впроваджувати передовсім у заочних відділах університетів.

Висновки та перспективи подальших досліджень. Інформатизація суспільства зумовила ширше використання новітніх комп'ютерних технологій у різних сферах життєдіяльності людини. Наразі вони можуть виступати одним з інструментів пізнання, у тому числі, і отримання вищої освіти. Стрімкі глобалізаційні процеси вплинули на особистісну, соціальну та культурну сферу життя громадян. Руйнування теперішніх бар'єрів відбулося 3 причини впровадження супутникового зв'язку та відкриття вільного доступу до Всесвітньої мережі Інтернет.

Сучасна освіта повинна мати на меті підготовку фахівців, котрі будуть вільно орієнтуватися у світового інформаційному просторі, шукати, обробляти та зберігати потрібну їм інформацію, володіти відповідними знаннями і навичками, а також використовувати новітні комп'ютерні технології. Електронне навчання має сформувати глобальний освітній простір. Варто його сприймати насамперед як метод досить ефективного доповнення традиційних форм отримання освіти. У такий спосіб можна усунути деякі нагальні недоліки останніх. Перспективність напрямку розвитку дистанційної форми навчання обумовлена тим, що освіта є великою системою, функціонування якої неможливе без використання новітніх комп'ютерних та телекомунікаційних технології, що допомагають зберігати, опрацьовувати, передавати і подавати інформацію.

Завдяки електронній освіті студенти отримують доступ до нетрадиційних джерел інформації. Вона значно підвищує ефективність самостійної роботи, формує творчі здібності, а також сприяє пошуку і закріпленню професійних навичок. 3 боку викладачів дистанційне навчання допомагає у застосуванні концептуального моделювання явищ та процесів.

Електронна освіта в Україні та світі з часом буде розвиватися на фоні удосконалення технологій і зміни теперішніх методів викладання. Серед актуальних напрямів подальшої роботи можна відзначити аналіз практики застосування дистанційного навчання та роботи ЗВО у новій формі. Таким чином можна уточнити деякі базові поняття, а також зробити теоретичне обгрунтування психолого-педагогічних принципів застосування новітніх технічних засобів.

\section{ЛІТЕРАТУРА}

1. Безрученков Ю.В. Професійна освіта майбутніх фахівців готельно-ресторанного господарства в умовах дистанційного навчання Проблеми інженерно-педагогічної освіти : зб. наук.пр. Укр. інж.-пед. акад. ; голов. ред. д-р 
пед. наук, проф. Д.В. Коваленко. Харків, 2020, № 68. С. $69-80$.

2. ДмитренкоГ.,ПомиткінЕ.,ГоловачН. Формування здатних до самореалізації здобувачів освіти в умовах глобалізованого світу. Молодь і ринок. Щомісячний науково-педагогічний журнал. Дрогобич, № 1(180) січень 2020. С.12-18.

3. Електронна освіта. Інформаційний ресурс URL: https://uk.wikipedia.org (дата звернення: 30.04.2021)

4. Кронівець Т. М. Правове регулювання дистанційної освіти в Україні: сучасний стан та перспективи розвитку. Правова інформатика. Київ 2013, № 2 (38). URL: http://ippi.org.ua/ kronivets-tm-pravove-regulyuvannya-distantsiinoiosviti-v-ukraini-suchasnii-stan-ta-perspektivi-rozv (дата звернення: 30.04.2021)

5. Про Основні засади розвитку інформаційного суспільства в Україні на 2007-2015 роки : закон Украӥни від 9 січ. 2007 р. № 537-V. Відомості Верховної Ради України. Київ 2007, № 12. Ст. 102.

6. Про деякі питання організації дистанційного навчання. Наказ Міністерство Освіти і Науки Украӥни № 1115 від 08 вересня 2020 року. URL: https://zakon.rada.gov.ua/ (дата звернення: 30.04.2021)

7. Стратегія розвитку інформаційного суспільства в Україні : розпорядження Кабінету Міністрів Украӥни від 15 трав. 2013 р. № 386-р. URL: http://zakon.rada.gov.ua (дата звернення: 30.04.2021)

8. Чорна О. А. Педагогічні аспекти електронного (дистанційного) навчання з точки зору зарубіжних дослідників. XIV Міжнародна наукова інтернетконференція Advanced technologies of science and education. Збірник матеріалів конферениіï. URL: http://intkonf.org/index.php?s=\%F2\&paged $=395$ (дата звернення: 30.04.2021)

\section{REFERENCES}

1. Bezruchenkov, Yu.V. (2020). Profesiina osvita maibutnikh fakhivtsiv hotelno-restorannoho hospodarstva $v$ umovakh dystantsiinoho navchannia Problemy inzhenerno-pedahohichnoi osvity [Professional education of future specialists of hotel and restaurant industry in the conditions of distance learning]. Problems of engineering and pedagogical education: coll. ukr. eng.-ped. acad. Kharkiv, No. 68. pp. 69-80. [in Ukrainian].

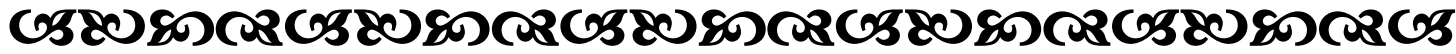

“Бути вчителем у ииброву добу - це навчати навичокмайбутнъого вже сьогодні". Dженібер Флеміне Університет штату Каліборнія
2. Dmytrenko, H., Pomytkin, E. \& Holovach, N. (2020). Formuvannia zdatnykh do samorealizatsii zdobuvachiv osvity v umovakh hlobalizovanoho svitu [Formation of self-fulfilling students in a globalized world]. "Youth and market". Monthly scientificpedagogical journal. Drogobych,Vol.1(180), pp. 12-18. [in Ukrainian].

3. Elektronna osvita [E-learning]. Information resource. Available at: https://uk.wikipedia.org (accessed 30. Apr.2021). [in Ukrainian].

4. Kronivets, T. M. (2013). Pravove rehuliuvannia dystantsiinoi osvity v Ukraini: suchasnyi stan ta perspektyvy rozvytku [Legal regulation of distance education in Ukraine: current state and prospects of development]. Monthly journal Legal informatics. Kyiv, No. 2 (38). Available at: http://ippi.org.ua/ kronivets-tm-pravove-regulyuvannya-distantsiinoiosviti-v-ukraini-suchasnii-stan-ta-perspektivi-rozv (accessed 30. Apr.2021). [in Ukrainian].

5. Pro Osnovni zasady rozvytku informatsiinoho suspilstva v Ukraini na 2007-2015 roky (2007). [On the Basic Principles of Information Society Development in Ukraine for 2007-2015]. Law of Ukraine of January 92007 No. 537-V. Information of the Verkhovna Rada of Ukraine. Kyiv, No. 12. 102 p. [in Ukrainian].

6. Pro deiaki pytannia orhanizatsii dystantsiinoho navchannia (2020). [On some issues of distance learning]. Order of the Ministry of Education and Science of Ukraine No.1115 of September 8, Kyiv, Available at: https://zakon.rada.gov.ua/ (accessed 30. Apr.2021). [in Ukrainian].

7. Stratehiia rozvytku informatsiinoho suspilstva v Ukraini (2013). [Strategy of information society development in Ukraine]. Order of the Cabinet of Ministers of Ukraine of May 15. 2013 No. 386. Available at: http://zakon.rada.gov.ua (accessed 30. Apr.2021). [in Ukrainian].

8. Chorna, O. A. (2019). Pedahohichni aspekty elektronnoho (dystantsiinoho) navchannia z tochky zoru zarubizhnykh doslidnykiv [Pedagogical aspects of e-learning from the point of view of foreign researchers]. Collection of conference materials. XIV International Scientific Internet Conference advanced technologies of science and education. Available at: http://intkonf.org/index. php? $\mathrm{s}=\%$ F2\&paged=395 (accessed 30. Apr.2021). [in Ukrainian].
Стаття надійшла до редакції 22.03.2021 